\title{
ANALYSIS OF THE INFLUENCE OF BANK FUND MANAGEMENT IN KALSEL BANKS 2015-2019 PERIOD.
}

\section{Qutwendra Elva Hibtiyanti}

Master of Management, Ahmad Dahlan University, Yogyakarta Email : qutwendra@gmail.com

\begin{abstract}
This study aims to analyze the management of funds at the Bank of South Kalimantan for the period 2015 to 2019, namely to find out how to determine the amount of funds needed to support the operational activities of the Bank of South Kalimantan as well as the methods of collecting funds carried out by the Bank of South Kalimantan. In this study, the data source used was the annual report of the South Kalimantan Bank for the period 2015-2019. This research resulted in the Bank of South Kalimantan determining the funds needed to support bank operational activities based on Government Regulations, Minimum Bank Provision Requirement (KPMM), bank operational area, liquidity requirements owned, and the quality level of assets. Meanwhile for good bank fundraising policy Bank of South Kalimantan in accordance with the policy direction of the Regional Champion Program which consists of 3 main pillars, namely (1) improving and protecting bank defense (2) serving as regional development agents and (3) increasing expertise in providing services to communities in the regions.
\end{abstract}

Keywords: bank fun, and management bank. 


\section{INTRODUCTION}

Bank fund management is the process of collecting and managing funds from the public into the bank, where the allocation of these funds is used for the benefit of the bank as well as the public with the aim of achieving an appropriate and adequate level of profitability with the requirements of the applicable regulations. There are several things that make fund management important, namely (a) banks as financial institutions acting as intermediaries for transferring funds from having excess funds to those with lack of funds by means of indirect financing (b) bank fund management always has to deal with the complications of interest between profitability and liquidity, (c) the principle of prudence is very valuable in fund management, especially in its determination so that the funding structure is healthy, 1

There are four main problems in fund management according to Melayu SP Hasibuan, namely (a) how and how much is the amount of funds set to support bank operations, (b) how the policies for collecting and withdrawing funds are needed, (c) how to determine the various ways to raise funds banks, and (d) how the forms of monitoring of fund collection and withdrawal are carried out.

Bank South Kalimantan as one of the banks that helps develop the regional economy and already has several branches and sub-branches. Becoming a market leader or market leader is important in the success of a regional bank so that there will be continuous improvement. Therefore, it takes effort and hard work in carrying out improvements to strengthen the competitive position. The reputation of the bank's business is one of the important factors in fund

${ }^{1}$ Ikit. 2017. Islamic Bank Fund Management. Yogyakarta: Gava Media 
management, which consists of financial performance, integrity, catalyst and credibility carried out by the management in the bank.

Several ways that the Bank of South Kalimantan has taken to create a good bank business reputation, namely by increasing all parts of the strength of the business organization, especially those that contribute to the performance of intermediation. Increased prudence is also carried out on business expansion, as well as increasing compliance and consolidation on the principles of good management up to the level of bank operational procedures. As a matter of priority, strengthening human resources is also carried out on an ongoing basis to strengthen infrastructure, superstructure and business structures and all those who support them.

Previous research was conducted by Nurmasari to determine the process of raising funds for Islamic banks and the obstacles they face. This research has resulted in many problems faced by Islamic banking, at least there are six problems. Another study was conducted by BebyPraseliana ${ }^{2}$ (2014), by analyzing fund management at PT Bank Rakyat Indonesia, which resulted in the rejection of fund management at Bank Rakyat Indonesia in terms of the fund management ratio.

Another study was conducted by Wening ${ }^{3}$ (2018) who analyzed fund management at Islamic banks with conventional marketing perceptions. The result of the research is that optimal fund management is still needed and it needs to be developed again in Islamic banks, so that customer trust, both

\footnotetext{
2 Praseliana, Beby. 2012. Fund Management Analysis at PT. Bank Rakyat Indonesia

3 Purbadin, Wening. 2018. Analysis of Islamic Bank Fund Management in Conventional ${ }^{4}$ Marketing Concepts. Journal of Islamic Law, Economics and Business, 1-17
} 
seasonal and non-Muslim customers, is no exception, so that they can compete with conventional banks.

Based on a description of the importance of fund management in an organization, especially fund management in a bank. So, this study was conducted to analyze Bank Fund Management at South Kalimantan Banks for the period 20152019.

\section{LITERATURE REVIEW}

1. Bank Funds

a. Definition of Bank Funds

Current assets or cash are owned by banks, and can be cashed at any time called bank funds ${ }^{4}$ (Kasmir: 2007) Bank is a financial institution whose activities are related to fund issues. In Indonesia, banking consists of Conventional Banks and Sharia Banks.

The functions of bank funds include:

a. as a source of funds for the bank's own operational activities

b. in order to comply with Bank Indonesia regulations

c. as a source of primary or secondary investment funds for the bank

d. to buffer losses from the bank

e. be a benchmark for the size of the bank

f. to strengthen public sympathy for the bank

g. to strengthen bank competition

h. to increase the number of branch office openings

b. Source of Bank Funds

The source of bank funds comes from the efforts made by banks in collecting public funds. The funds collected must be safeguarded for the safety and 
benefit, meaning that the funds obtained must be managed professionally in order to get the highest profit.5(Purbadin, 2018)

There are two sources of bank funds, namely internal and external sources. Internal sources are funds originating from within the bank, including capital deposits / sale of shares, accumulation of reserves, retained earnings, etc., these funds are fixed in nature. Meanwhile, funds from external sources are funds from outside banks or third parties, including deposits, demand deposits, call money, and others. These funds are temporary and must be returned.

c. Determination of Funds Needed to Support Bank Operational Activities

Determining the need for bank funds can be determined from several things, namely:

1) Provisions from the Government

The government of each country makes a policy on the own capital of each bank which is regulated in a Law, Presidential Decree, or a circular letter from Bank Indonesia.

Bank Indonesia Regulation Number 14/26 / PBI / 2012 dated 27 December 2012 concerning Business Activities and Office Networks Based on Bank Core Capital

2) Minimum Capital Adequacy Requirement (KPMM)

KPMM or CAR is the minimum capital required by the bank and is calculated based on risk weighted assets.

\footnotetext{
5 Purbadin, Wening. 2018. Analysis of Islamic Bank Fund Management in Conventional Marketing Concepts. Journal of Islamic Law, Economics and Business, 1-17
} 
Financial Services Authority Regulation Number 11 / POJK.03 / 2016 concerning Minimum Capital Requirement for Commercial Banks.

3) Bank Operational Area If the operational area of a bank becomes wider, both nationally and internationally, the greater the funds required by the bank will also increase.

4) Bank Service Products

The more services a bank provides, the greater the funds needed by the bank, and vice versa.

5) Purpose of the Bank

The purpose of the bank has an effect on bank funds, because the large amount of profit targeted by the bank will increase the required bank funds.

6) Chairman of the Bank

The professionalism of bank leaders has an effect on bank capital needs.

7) Liquidity Needs owned

To meet liquidity, it can be taken from bank capital. This can happen because the bank does not have sufficient liquidity

8) Quality Level of Assets

Capital requirements will be easily fulfilled if the bank has several productive assets, such as current credit.

9) Structure of Savings

It will be increasingly difficult to meet capital, if the cost of savings is greater or greater.

10)Quality Level and Operational System of the Bank

The more efficient and productive a bank is if the bank's operations run well.

11)Bank Owner's Quality Level 
If the owner of the bank reinvested the profits he earned, the capital requirements would be more easily met.

d. Bank Funds Collection Policy

In order to obtain effective and efficient funds, the policy setting for collecting funds must be managed appropriately. There are two sources of fundraising policies, namely internal and external.

1) Internal source fundraising policy

a) Sale of portfolio shares

A collection of investment assets in the form of stocks, which can be owned by companies or individuals, is called a stock portfolio. This policy can be implemented by selling portfolio shares whose nominal value is above the shares in order to get a share premium.

b) Increase in share value

This policy can be implemented while remaining based on the nominal value at the GMS to increase the value of a share.

c) Issuance of new shares

This policy is implemented with the aim of collecting the necessary funds from the bank.

d) Profit reinvestment

This policy is implemented by holding a portion of the profit so that it can be used as capital to reinvest.

2) Policy on collecting funds from external sources

a) Retail policy

If all the people will be the source of the funds, then this can be done by the bank by accepting small initial deposits, so that all people have the opportunity to save money 
in the bank, not only from the conglomerate group.

b) Distribution policy

This means that if the funds withdrawn come from the middle and upper economic groups.

c) Interest rate policy

If the higher the interest rate, it means the bigger the savings.

d) Time policy

If the time for savings is getting longer, the interest rate will also be higher.

e) Gift giving policy

The giving of gifts is carried out so that the interest of the owner of the money becomes high in saving money.

f) Savings search policy

Through ATM facilities, banks make it easier to disburse savings, while time deposits can only be withdrawn before the deadline, even though they receive a penalty for the interest that has been received by the customer.

\section{RESEARCH METHODS}

Explain in detail about the research design, settings, time frame, variables, population, samples, sampling, instruments, data analysis, and information of ethical clearance fit test. The method of this paper is library method, library method is the method that emphasize the use of literature as the primary data source. This research is a quantitative study that applies the Johansen Integration Test and Vector Error Correction Model to see the long-term impact and shock response on certain variables...(Cambria, 12, Justify)

Formulas using equation 
$R t=\ln (P t-P t-1)+\frac{\alpha}{\beta}$

\section{RESULT AND ANALYSIS}

This research is sourced from secondary data, namely the annual report of the Bank of South Kalimantan for 2015 to 2019 related to the main problems in bank fund management and fund collection products for the Bank of South Kalimantan. In this study, the authors analyzed the data and information obtained from the annual report Bank of South Kalimantan to answer four main problems in fund management. Furthermore, the Bank of South Kalimantan annual report is also used to process information about funding products Bank of South Kalimantan to draw conclusions.

\section{RESULTS AND DISCUSSION}

The main problems of fund management studied were how to determine the funds needed to support bank operations, and bank fund collection policies.

1. Amount and Method of Determining Funds Needed to Support Bank Operational Activities

a. Government Provisions

According to the determination of the Bank's business activity group, South Kalimantan Banks are included in BUKU II with a minimum core capital of IDR 1 trillion.

The total capital of Bank South Kalimantan in 20152019 is shown in table 1.0

Table 1.0 Bank South Kalimantan Capital 2015-2019

\begin{tabular}{|l|l|l|l|l|l|}
\hline nformation & 2015 & 2016 & 2017 & 2018 & 2019 \\
\hline otal capital & 512,925 & 594,744 & 558,815 & 771,775 & 940,157 \\
\hline
\end{tabular}

Source: Bank of South Kalimantan Annual Report

The table above shows that each year the capital of the South Kalimantan Bank has exceeded the minimum limit. 
b. Minimum Capital Adequacy Requirement (KPMM)

Table 1.1 KPMM according to the risk of Bank Kalsel 2015-2019

\begin{tabular}{|l|l|l|l|l|l|}
\hline ormation & 15 & 16 & 17 & 18 & 19 \\
\hline MM according to risk & $91 \%$ & $89 \%$ & $81 \%$ & $63 \%$ & $63 \%$ \\
\hline
\end{tabular}

Source: Bank of South Kalimantan Annual Report

\begin{tabular}{|c|l|c|c|c|c|c|}
\hline \multirow{2}{*}{ No. } & \multirow{2}{*}{ Office Network } & \multicolumn{5}{|c|}{ Year } \\
\cline { 3 - 7 } & & 2015 & 2016 & 2017 & 2018 & 2019 \\
\hline 1 & Headquarters & 1 & 1 & 1 & 1 & 1 \\
\hline 2 & Branch office & & & & & \\
\hline & - Main Branch & 1 & 1 & 1 & 1 & 1 \\
\hline & - Conventional Branch & 14 & 14 & 14 & 14 & 14 \\
\hline & - Sharia Branch & 2 & 2 & 2 & 2 & 2 \\
\hline 3 & Branch office & & & & & \\
\hline & - Conventional Sub Branch & 9 & 9 & 9 & 9 & 9 \\
\hline & - Sharia Sub-Branch & 1 & 2 & 2 & 2 & 2 \\
\hline 4 & Unit Office / Store & & & & & \\
\hline & - BPD Unit & 23 & 25 & 25 & 27 & 27 \\
\hline & - Sharia Shop & 7 & 7 & 7 & 7 & 7 \\
\hline 5 & Cash office & & & & & \\
\hline & - Conventional Cash Office & 18 & 19 & 24 & 24 & 24 \\
\hline & - Sharia Cash Office & 3 & 3 & 3 & 3 & 3 \\
\hline 6 & Car Cash & 15 & 18 & 21 & 24 & 24 \\
\hline 7 & Automatic Teller Machine & & & & & \\
& (ATM) & & & & & \\
\hline & - Conventional ATM & 169 & 190 & 210 & 210 & 277 \\
\hline & - Sharia ATM & 15 & 15 & 20 & 20 & 25 \\
\hline & - ATM Mobile & 5 & 5 & 5 & 5 & 5 \\
\hline & - ADM & 1 & 1 & 1 & 1 & 1 \\
\hline 8 & Payment Point & 20 & 37 & 48 & 51 & 60 \\
\hline
\end{tabular}




\begin{tabular}{|c|l|c|c|c|c|c|}
\hline & SerambiSyariah & - & - & - & - & 10 \\
\hline 9 & Sharia Service Unit & 46 & 48 & 48 & 48 & 49 \\
\hline
\end{tabular}

The table above shows that the KPMM of the South Kalimantan Bank is in accordance with the 0JK regulations regarding the KPMM of the Bank.

c. Bank Operational Area

The operational area of Bank South Kalimantan in 2015-2019 is shown in table 1.3

Table 1.2 Operational Area of South Kalimantan Bank

Source: Bank of South Kalimantan Annual Report

Bank Kalsel since 2015-2019 has expanded several operational areas, so that the need for bank funds is also getting bigger

d. Liquidity Needs owned

The following is the development of Bank South Kalimantan liquidity according to the 2015-2019 Financial Highlights.

Table 1.3 Bank Kalsel Liquidity Development

\begin{tabular}{|c|ll|l|l|l|}
\hline \multirow{2}{*}{ Financial Data } & \multicolumn{5}{|c|}{ Year } \\
\cline { 2 - 6 } & 2015 & 2016 & 2017 & 2018 & 2019 \\
\hline Liquidity & & & & & \\
\hline - LDR & $00.55 \%$ & $6.53 \%$ & $3.89 \%$ & $39.73 \%$ & $95.26 \%$ \\
\hline
\end{tabular}

Source: Bank of South Kalimantan Annual Report

In Harun's research, it was stated that the Bank Indonesia Regulation concerning LDR / Loan to Deposit Ratio, namely the ratio between $80 \%$ to $110 \%$. The more the profit increases, the higher the LDR. This means that the bank has 
distributed its credit effectively ${ }^{6}$. The LDR of South Kalimantan banks from 2015 to 2019 is still in the safe limit of the LDR of a bank.

e. Quality Level of Assets

The following is the development of Bank South Kalimantan assets according to the 2015-2019 Financial Highlights

Table 1.4 Asset Development

\begin{tabular}{|c|c|l|l|l|l|}
\hline \multirow{2}{*}{ nancial Data } & \multicolumn{5}{|c|}{ Year } \\
\cline { 2 - 6 } & 2015 & 2016 & 2017 & 2018 & 2019 \\
\hline Asset & $0,987,597$ & $, 895,221$ & $, 898,168$ & $, 182,395$ & $, 954,838$ \\
\hline
\end{tabular}

Source: Bank of South Kalimantan Annual Report

The need for capital will be more easily fulfilled if there are more productive assets.

2. Bank Funds Collection Policy

Bank of South Kalimantan in collecting funds from the public is in accordance with the direction and policies of the Regional Champion Program. This policy consists of 3 main pillars, 3 main pillars, namely (1) improving and protecting the defense of the bank (2) acting as an agent for regional development and (3) increasing expertise in providing services to the community in the regions.

Further information regarding the BPD Regional Champion Pillar policy in raising public funds, namely:

- To realize Pillar 1, improve bank defense, the South Kalimantan Bank is committed to increasing efficiency and capital in order to meet a good level of profitability, so that credit with competitive interest rates can be extended to the public.

${ }^{6}$ Harun, Usman. 2016. The Influence of Financial Ratios CAR, LDR, NIM, BOPO, NPL, Against RO. Journal of Business Research and Management Vol 4, No 1, 67-82 
- Act as regional development agency in Pillar 2, Bank of South Kalimantan in the productive sectors provide a bigger target in credit. By increasing the intermediation function in MSMEs in collaboration with BPRs, either as APEX Banks or via linkage programs.

- In order to increase expertise in providing services to the community in Pillar 3, Bank South Kalimantan will improve the quality of human resources and will have a standardization program, by increasing broad access and also expanding office networks in order to realize a comprehensive financial system.

In collecting bank funds, The business model used by the Bank of South Kalimantan is a customer centric strategy, which is a marketing approach made on the basis of understanding the wants and needs of the customers of the Bank of South Kalimantan. With this understanding, it is then made into necessary products and services, until they are sold or distributed using a distribution channel that focuses on the target segment of each customer.

The supervisory system for fundraising for the Bank of South Kalimantan is carried out by internal and external supervision. Internal supervisor is the board of commissioners. Meanwhile, external supervision is carried out by a Public Accountant Office (KAP). Where the public accountant as an External Auditor has a role to provide an assessment of the results of reports that have been done by the management of the Bank of South Kalimantan in a neutral, rational and factual manner.

Bank Kalsel products and services, namely, for savings products, including the Simpeda Savings, Banua Savings, Haji Ar Rahman Savings, Tabunganku and Simpel Savings. For current accounts, there are online current accounts, while for time deposit products, among others are Time Deposits, Banua Deposits, Weekly Deposits and On Call Deposits. Whereas for 
service products, namely BPD Net Online, Money Charger, Payment Points, Sikdo, Online Taxes, Safe Deposit Boxes, Money Transfer Facilities, Collection and Bank Guarantee.

Products and Services of South Kalimantan Bank have an effect on the amount of bank funding needs. In the range of 2015 to 2019 there was no increase in many bank products or services, so that the bank funds needed for products and services at Bank Kalsel or Bank KalselSyariah did not change much, it can be seen from the capital structure of Bank South Kalimantan in 2015 - 2019 in table 1.0

\section{CONCLUSION}

From the research results described in the previous chapter, there are the following conclusions:

1. In determining the funds needed to support bank operations in 2013-2017, South Kalimantan banks are determined based on Government Regulations, Minimum Bank Provision Requirements (KPMM), bank operational areas, liquidity requirements held, and the quality level of assets.

2. The bank's fundraising policy is good Bank Kalsel and Bank KalselSyariah in accordance with the policy direction of the Regional Champion Program which consists of 3 main pillars, namely (1) improving and protecting bank defense (2) serving as regional development agents and (3) increasing expertise in providing services to communities in the regions.

In collecting bank funds, The business model used by the Bank of South Kalimantan is a customer centric strategy, which is a marketing approach made on the basis of understanding the wants and needs of the customers of the Bank of South Kalimantan 


\section{BIBLIOGRAPHY}

Praseliana, Beby. 2012. Fund Management Analysis at PT. Bank Rakyat Indonesia

Defiyani, Atiek. 2011. Bank Fund Management

Harun, Usman. 2016. The Influence of Financial Ratios CAR, LDR, NIM, BOPO, NPL, Against RO. Journal of Business Research and Management Vol 4, No 1, 6782

Ikit. 2017. Islamic Bank Fund Management. Yogyakarta: Gava Media

Kulsum, Ummi. 2018. Sharia Banking Supervision Authority in Indonesia. Journal of Islamic Economics and Business Studies Volume 3, Number 2, 1-12

Purbadin, Wening. 2018. Analysis of Islamic Bank Fund Management in Conventional Marketing Concepts. Journal of Islamic Law, Economics and Business, 1-17

Sari, Nurma. Islamic Bank Fund Management

Sunaryo, Farida. 2007. Accounting for Fund Receipts and Fund Management at PT Bank Rakyat Indonesia

Thank God, Ali. 2012. Regulation and Supervision of Sharia Banks. Journal of Islamic Economics and Law, Vol 2, No.1, 1-20

Widodo. 2017. Popular and Practical Research Methodologies. Depok: PT RajagrafindoPersada 